\title{
Mutagenic potential of Gamma rays on Somatic cell division and morphological parameters in Foeniculum vulgare Mill.
}

\author{
Girjesh Kumar, Moni Mishra* \\ Naithani Plant Genetics Laboratory, Department of Botany, University of Allahabad, Prayagraj-211002, Uttar Pradesh, India
}

Received: December 02, 2020 Revised: March 12, 2021 Accepted: March 17, 2021 Published: March 29, 2021

*Corresponding Author: Moni Mishra Email: mmoni261296 @gmail.com

\begin{abstract}
Mutagenesis involving ionizing radiation has been widely used for alteration in genetic constituents to increase the variability at gene level in a very small fraction of time. But, attempts to induce genetic variability in fennel for agronomically important trait are very limited. Narrow genetic base is the main hindrance in handling the conventional breeding in Fennel .Thus, main idea of this study is to generate genetic variability in Ajmer fennel-2 variety of Foeniculum vulgare Mill. by using the most potent physical mutagen i.e. gamma rays. The seeds were exposed to different doses of gamma rays viz. 5, 10, 15, 20 and $25 \mathrm{Kr}$, respectively, along with control to analyze the effect of gamma rays on meristematic root tips. Germination and survival percentage were significantly affected in response to ionizing potential of gamma rays and a dose dependent decline was observed in both the parameters. Plant height, shoots, root length and days of flowering were also affected by gamma rays and a considerable increment was achieved at lowest dose with respect to control. As the dose of gamma ray increases, the rate of Active Mitotic Index declines. The irradiated seeds show numerous chromosomal variations such as; scattering, stickiness, bridge formation etc which are computed in the form of Total Abnormality Percentage.
\end{abstract}

KEYWORDS: Active Mitotic Index, Foeniculum vulgare Mill, Gamma rays, Mutation, Total Abnormality Percentage

\section{INTRODUCTION}

Concerns about food security are increased depending on the raised world population. To feed the world population might be possible if the food production increases double by 2050 . However, this aim is associated with many climate-based comprehensive challenges. Plant breeders take effort to change genetic structures of the plants to improve preferred food by humans. Although classical breeding techniques have presented knowledge of genetic structure of plants, modern breeding such as genetic engineering and mutation breeding give much more information than traditional breeders, the conventional breeding cannot be an appropriate option to improve new characters (Harten, 1998; Ahloowalia \& Maluszynski, 2001). Mutation breeding has become a proven way of including alteration in genetic constituents to increase the variability at gene level in a very small period of time crop. Increasing world food security is the main aim for mutation breeding to increase crop production (Kharkwal \& Shu, 2009).By using different type of physical and chemical mutagens. Ionizing radiations are also used to sterilize some agriculture product to increase the conservation time and decrease the pathogen propagation when trending these product with the same or from country to country (Melki \& Sallami, 2008). Gamma rays are known to be more popular mutagen for their simple application, good penetration, less disposal problems, higher mutation frequency and reproducibility (Chahal \& Gosal, 2002). It is most energetic form of electromagnetic radiation, their energy level is from ten to several hundred kilo electron volts and have high penetration power as compared to other physical mutagens (Kovacs \& Keresztes, 2002).

Ionizing radiation damages the cell either by directly or indirectly. (i) Direct effect- where DNA is the direct target and radiation energy is directly absorbed by it. (ii) Indirect effect- where the initial absorption of energy is by other molecules in the cell. Subsequently this energy or the products of this energy (highly reactive free radicals) can be transferred to DNA. These free radicals can induce damage in cellular membranes, and create change in plastid structure and mitochondria Kovacs and Keresztes (2002) and fragmentation of the endoplasmic reticulum, Golgi apparatus, and also create change by breaking the bonds in DNA and various proteins (Somosy, 2000). Under normal conditions it is difficult to separate these effects and so, cumulative effect of both direct and indirect effects of radiations is observed. The most prominent effect of ionizing radiation to change the structure of DNA, cross linking of DNA-DNA and DNA-proteins, ,removal of a base and change in chemical structure of bases that change

Copyright: (C) The authors. This article is open access and licensed under the terms of the Creative Commons Attribution License (http://creativecommons.org/licenses/by/4.0/) which permits unrestricted, use, distribution and reproduction in any medium, or format for any purpose, even commercially provided the work is properly cited. Attribution — You must give appropriate credit, provide a link to the license, and indicate if changes were made. 
pairing properties of the DNA strand (Casarett, 1968). While cross linking of DNA leads to the cell death, the strand breaks result in chromosomal mutations, Gamma radiation can be used for alteration of morphology including seed germination, shoot elongation and root elongation and physiological characters which include change in plant cellular structure and metabolic, alteration in photosynthesis modulation of antioxidant system causes the decline in photosynthetic pigment (Ling et al., 2008; Ashraf, 2009).

Foeniculum vulgare Mill is native of Southern Europe and Asia and it is an aromatic annual herb, having yellow flowers (Khan $\&$ Musharaf, 2014). Fennel is commonly used as flavoring agents in bread, cheese pharmaceuticals and nutraceuticals and also used as used as antispasmodic, diuretic, anti-inflammatory and antioxidant cure (Moura, 2005). The present investigation was extensive study of mutagenic effectiveness and potency of different doses of gamma irradiation on morphology as well as cytology of fennel plant. Improvement in any character of the plant the most important requirement is to available variability in the gene pool. The variability may be created by mutation. Diminutive efforts have been made to improve fennel crop through genetic manipulation. Since, induced mutagenesis can be a better way to improvement of the variability in most of spice crops including fennel also (Verma et al., 2017).

\section{MATERIAL AND METHODS}

\section{Seed Procuremen}

Pure inbred lines of the seed of Foeniculum vulgare Mill. (AF-2) were collected from ICAR- National research center on seed spices. Ajmer, Rajasthan.

\section{Gamma Treatment}

Dry seeds of Foeniculum vulgare Mill. were irradiated with different doses of gamma rays $5 \mathrm{Kr}, 10 \mathrm{Kr}, 15 \mathrm{Kr}, 20 \mathrm{Kr}$ and $25 \mathrm{Kr}$ in Gamma Chamber which containing $\mathrm{CO}^{60}$ as a source of gamma at NBRI, Lucknow - Irradiated seeds were allowed for germination on different petriplates in the germinator at optimum temperature and humidity. After germination, respective irradiated roots along with control were fixed in carnoy's fixative (1:3, Glacial Acetic Acid and Absolute alcohol) in labeled plastic bottles. The roots were preserved in $90 \%$ alcohol.

\section{Slide Preparation}

Slides were prepared for cytological study. First of all, roots were hydrolyzed in $1 \mathrm{~N} \mathrm{HCl}$ on water bath. After careful washing with distilled water, the roots were blotted on blotting paper, followed by staining in $2 \%$ acetocarmine. After staining, the darker stained root tips were excised and squashed in $2 \%$ acetocarmine mount. Slides were observed at $40 \mathrm{X}$ resolution and photographs were captured through PCTV software in Nikon phase contrast microscope. Active Mitotic Index (AMI\%) and Total Abnormality Percentage (TAB\%) were calculated. For each dose 10 slides were prepared and 10 microscopic fields were analyzed for each slide.

\section{Morphological Analysis}

Seeds of fennel with respect to control sown in the pots and each pot containing the 20 seeds per treated dose .Germination ,survivable percentages and plant height, root and shoot length for each treatment were subsequently determined. The treated seeds were then subjected to survivability test .based on reduction of survivability to 50 per cent, $\mathrm{LD}_{50}$ value was determined by using formula- Number of dividing cells. Active Mitotic index (AMI) $=$ Total number of dividing cells/ Total number of cells observed x 100; Total Abnormality Percentage $(\mathrm{TAB})=$ Total Number of Abnormal cells/ Total number of cells observed x 100

\section{Data Analysis}

Statistical analysis performed by using SPSS-16 software and ANOVA and graphs were plotted by using sigma plot 10.00 software.

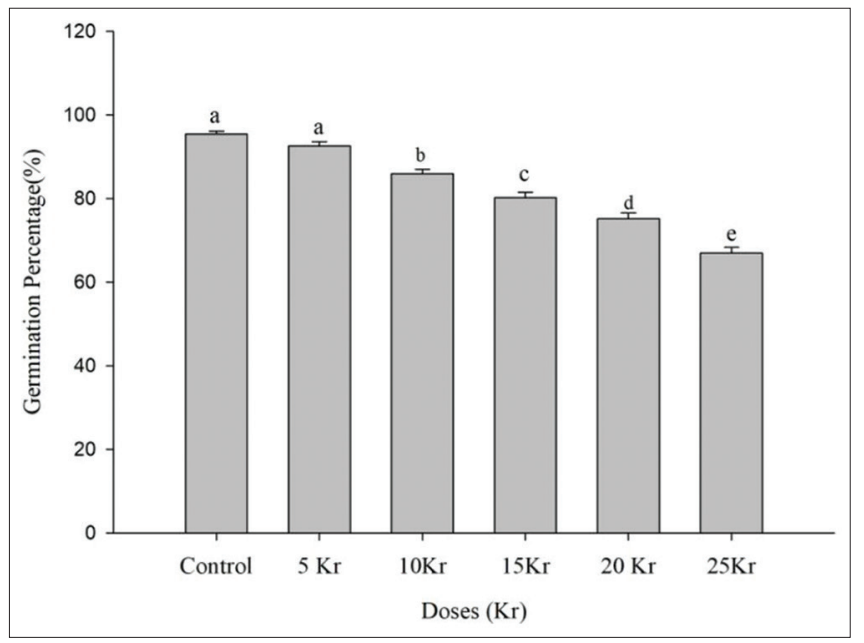

Figure 1: Effect of Gamma irradiation on Germination percentage in Foeniculum vulgare Mill.

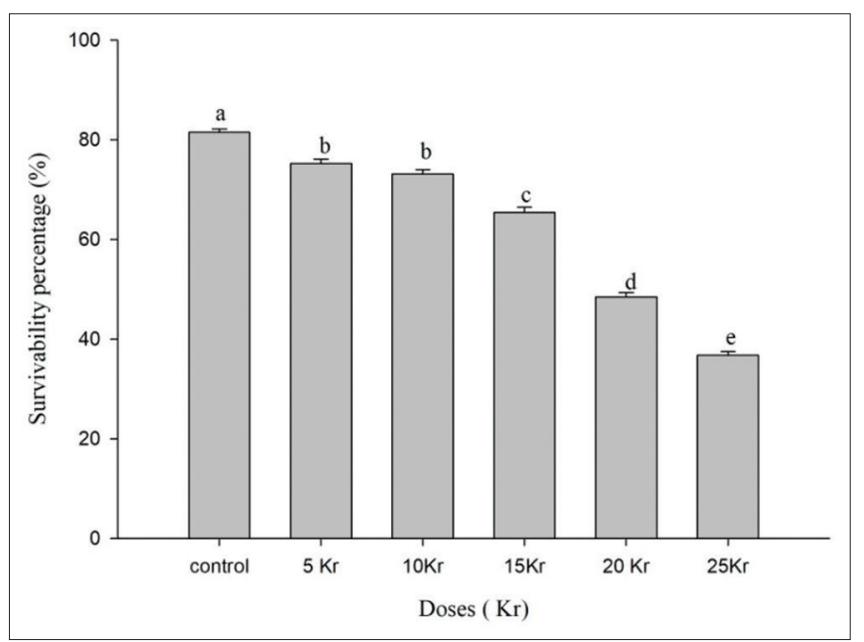

Figure 2: Effect of gamma radiation on survivability percentage in Foeniculum vulgare Mill. 


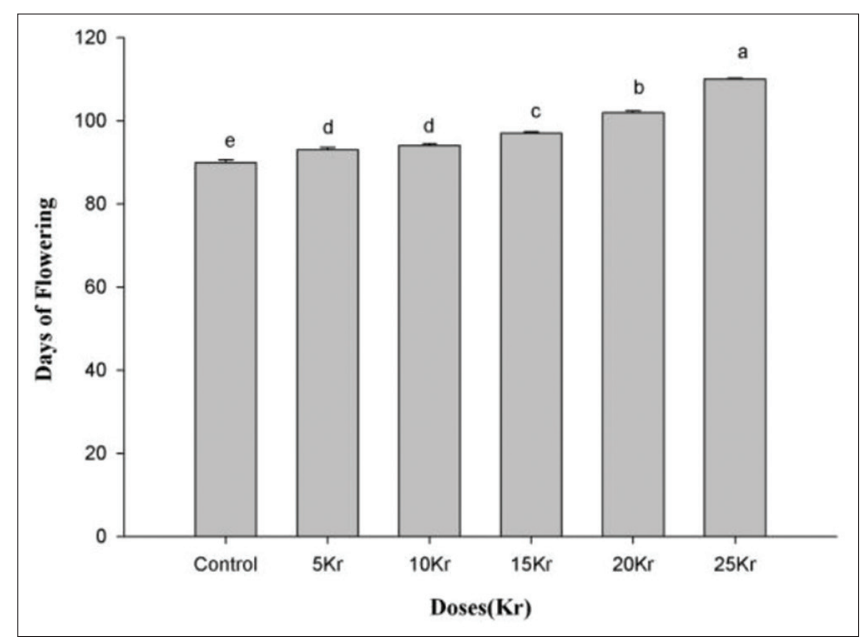

Figure 3: Effect of Gamma irradiation on Days of flowering in Foeniculum vulgare Mill.

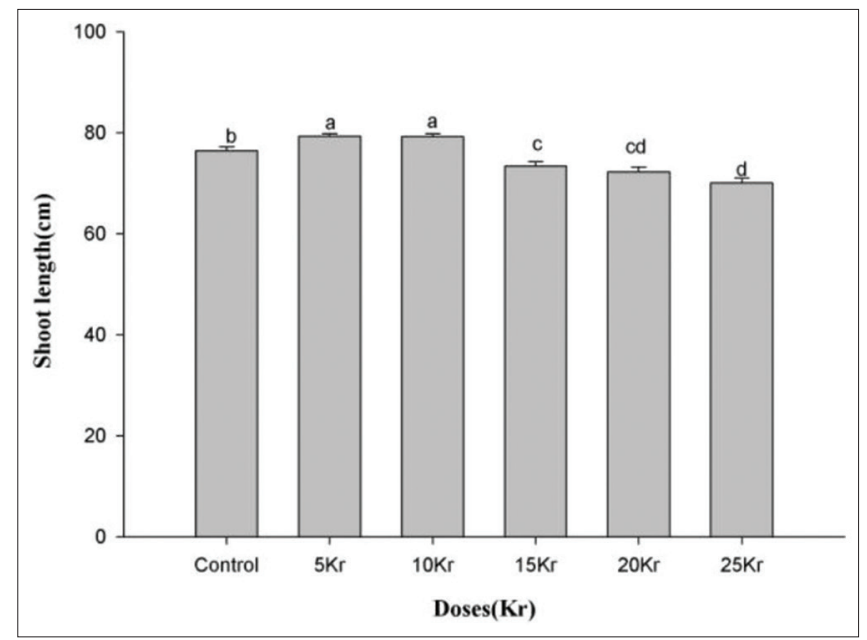

Figure 4: Effect of Gamma irradiation on Shoot length in $(\mathrm{cm})$ Foeniculum vulgare Mill.

\section{RESULTS}

The present investigation elucidates the effect of Gamma rays on Somatic cell division and morphological parameters in Foeniculum vulgare Mill.

\section{Morphological}

\section{Effect of Gamma irradiation on Germination, Survivability percentage}

The effects of gamma irradiation significantly reduced and delayed seed germination at $5 \mathrm{Kr}, 10 \mathrm{Kr}, 15 \mathrm{Kr}, 20 \mathrm{Kr}$ and $25 \mathrm{Kr}$ dose retarded seed germination and seedling survival significantly as compared to the control. The seed germination in control was recorded $95.4 \pm 0.66^{\mathrm{a}} \%$. It decreased along with increasing the doses of gamma radiations, whereas, lower doses of gamma radiation show stimulatory effect. Lowest germination $\%$ was observed in $25 \mathrm{Kr}$ i.e $\left(66.9 \pm 1.39^{\mathrm{e}} \%\right)$ (Figure 1). Survivability percentage was adversely affected at the higher doses of gamma radiation. This result revealed significant effects of

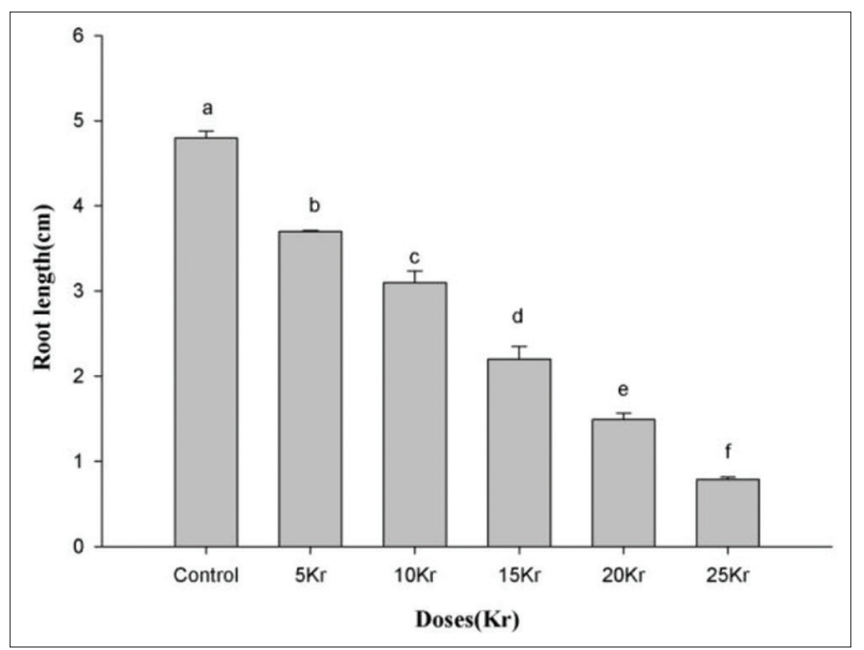

Figure 5: Effect of Gamma irradiation on Root length $(\mathrm{cm})$ in Foeniculum vulgare Mill.

the gamma rays treatments on survival \% of Foeniculum vulgare Mill. (Figure -2). All treatments (5, 10, 15, 20 or $25 \mathrm{Kr}$ ) significantly reduced the survival (\%) as compared to the control.

\section{Effect of Gamma irradiation on shoot, root length}

The effect of gamma rays on root and shoot length in this study was significantly inhibitory as is evident from data in Figures 3 and 4. The Seeds which exposed to higher doses of gamma rays that produced dwarf plants with reduced roots. The shoot length was taken before flowering. In control plant the shoot length was $76.5 \pm 0.70^{\mathrm{b}} \mathrm{cm}$ and it was reduced with the corresponding increase in the doses of gamma rays, being maximum $\left(79.3 \pm 0.46^{\mathrm{a}}\right)$ at $5 \mathrm{Kr}$ and minimum $\left(70.1 \pm 0.97^{\mathrm{d}}\right)$ at $25 \mathrm{Kr}$. Root length was taken after seedling germination and similar result was also observed in the root length.

\section{Effect of irradiation on days of flowering}

The result also revealed that the gamma rays significantly affected the number of days required for flowering in Figure 5. The gamma rays delayed the flowering in irradiated plants as compared to control plants $\left(90 \pm 0.67^{\mathrm{e}}\right.$ days $)$. Among the irradiated sets, early flowering was observed at $5 \mathrm{Kr}\left(93 \pm 0.54^{\mathrm{d}}\right.$ days $)$, followed by $10 \mathrm{Kr}$ ( $94 \pm 0.48^{\mathrm{d}}$ days), $15 \mathrm{Kr}\left(97 \pm 0.40^{\mathrm{c}}\right.$ days $), 20 \mathrm{Kr}\left(102 \pm 0.37^{\mathrm{b}}\right.$ days $)$ and $25 \mathrm{Kr}\left(110 \pm 0.33^{\mathrm{a}}\right.$ days $)$. Significant difference was observed at all the doses of gamma rays except for $5 \mathrm{Kr}$ and $10 \mathrm{Kr}$ with regard to delay in flowering as compared to control.

\section{Cytological}

Influence of gamma irradiation on AMI (Active Mitotic Index) and $T A B \%$

The effect of gamma irradiation on the plant was in a dose dependent manner. A highly significant decrease in AMI (\%) compared to the control was evident at all doses. Whereas, TAB (\%) increases in dose dependent manner, thus AMI and TAB percentages show inverse relationship. 
Highest AMI (\%) was recorded in control sets $\left(12.75 \pm 0.10^{\mathrm{a})}\right.$ which was reduced to $7.46 \pm 0.19$ at $25 \mathrm{kr}$. The ranges of AMI were found to be dose independent. Thus, the reduction in AMI could be clearly interpreted as cellular lethality. Whereas, the TAB (\%) shows the dose dependent relationship while the lowest TAB $(\%)$ was observed at $5 \mathrm{Kr}$ i.e. $2.65 \pm 0.17$, which shows elevation up to $6.41 \pm 0.05$ at $25 \mathrm{kr}$ dose. Significant decrease in AMI (Active Mitotic Index) reveals that gamma radiation is mito-depressive at higher doses radiation. The declination in active mitotic index occurs due to decreased DNA synthesis at S-phase of cell cycle (Sudhakar et al., 2001).

\section{Influence on chromosomal structure}

Percentage of various chromosomal abnormalities induced by gamma irradiation in the abnormal cells of root meristem of fennel plant is documented in Table 1.

\section{DISCUSSION}

\section{Morphological Analysis}

On the whole, growth and survivability characteristics of Fennel were significantly retarded with increasing doses of gamma irradiation. Germination percentage was significantly delayed by higher doses of gamma radiation. Due to inhibitory effect of gamma rays on seed dormancy causes delay in seed germination Similar results were also reported in many plant by Ahmad and Qureshi (1992) and Din et al. (2003) in Zea mays and Triticum aestivum L. Statistically maximum germination percentage was recorded at lowest dose of gamma irradiation as compare to control. Stimulatory effects of lower doses to seed germination has been reported in majority of other plant such as chickpea (Melki \& Sallami, 2008) and soybeans (Mudibu et al., 2011)

Survivability percentage was adversely affected at the higher doses of gamma radiation This, reduction caused due to the damage in plant tissue and breakdown of meristimatic cells (Mudibu et al., 2011). The $\mathrm{LD}_{50}$ values was calculated on the basis of $50 \%$ reduction of seedling survivability, which shows the lethal effect on the seed survivability approximately $50 \%$ of seed survival was observed at $20 \mathrm{Kr}$. Figure 2 Decrease in shoot and root lengths of a number of crops . Root length decreases along with increasing the dose of gamma irradiation as shown in Figure 4. This inhibitory effect of gamma rays on shoot and root length of plants was more pronounced at $20 \mathrm{Kr}$ and $25 \mathrm{Kr}$ (Figures 3 and 4) decreased shoot and root lengths at higher doses of gamma rays to reduced mitotic activity in meristematic tissues and reduced moisture contents in seed, respectively (Majeed \& Muhammad, 2010). Gamma rays significantly affected the number of days required for flowering. The results revealed that the maturity of fennel crop delayed by application of gamma rays (Verma et al., 2017). Similar results were also observed in ashwagandha (Bharathi et al., 2013). We also found the delay in flowering in gamma irradiated sets.

\section{Cytological Analysis}

Different microscopic views were analyzed from each dose for scoring the chromosomal aberrations which was found to be distributed at metaphases and anaphases. Control seeds showed a normal mitotic behaviour, perfect alignment of chromosomes on equatorial plate at metaphase $(2 n=22)$ (Fig. 6A) and 22:22 pole ward separation during anaphase (Figure 6.B). While, treated setes showed different types of chromosomal abnormalities which includes metaphasic plate distortion, unorientation at metaphase, stickiness, scattering, precocious movement at metaphase, laggard, bridge formation, etc. Chromosomal aberrations (CA) are extremely valuable for the study of variations created by mutagens. Most of the Chromosomal aberrations observed in cells are lethal, but some of them can cause genetic effects (Gadano et al., 2002). The most dominant chromosomal abnormality observed is scattering which occurs due to the loss of microtubules of spindles fibers, or may be attributed to disturbance in spindle formation. Kumar and Rai (2007) reported that scattering of chromosomes may be due to inhibition or destruction of spindle formation and also leading to the spindle fibre imbalance on both the sides of centromere fraction power or chromosome acentric fracture which cannot cause normal movement of chromosome (Fig. 6D). Stickiness was found in both metaphase and anaphase stage of mitosis, that leads to inactivation of DNA replication, as

Table 1: Effect of Gamma irradiation on the chromosomal morphology and Total Abnormality Percentage (TAB \%) in Foeniculum vulgare M

\begin{tabular}{|c|c|c|c|c|c|c|c|c|c|c|c|c|}
\hline \multirow{2}{*}{$\begin{array}{l}\text { Gamma } \\
\text { Treatment }\end{array}$} & \multirow{2}{*}{$\begin{array}{c}\text { MI (\%) } \\
(\text { Mean } \pm \text { SE) }\end{array}$} & \multicolumn{4}{|c|}{ Metaphasic abnormalities \% (Mean \pm SE) } & \multicolumn{5}{|c|}{ Anaphasic abnormalities \% (Mean \pm SE) } & \multirow{2}{*}{$\begin{array}{c}\text { Others \% } \\
(\text { Mean } \pm \text { SE })\end{array}$} & \multirow{2}{*}{$\begin{array}{c}\text { TAB (\%) } \\
(\text { Mean } \pm \text { SE) }\end{array}$} \\
\hline & & Sc & St & Un & $\mathrm{Pr}$ & $\mathrm{SC}$ & st & $\mathrm{Lg}$ & $\mathrm{Br}$ & un & & \\
\hline Control & $\begin{array}{c}12.75 \pm \\
0.10^{\mathrm{a}}\end{array}$ & - & - & - & - & - & - & - & - & - & - & - \\
\hline $50 \mathrm{~Gy}$ & $\begin{array}{c}11.73 \pm \\
.08^{\mathrm{b}}\end{array}$ & $\begin{array}{c}0.37 \pm \\
0.18\end{array}$ & $\begin{array}{c}0.31 \pm \\
0.15\end{array}$ & $\begin{array}{c}0.34 \pm \\
0.17\end{array}$ & - & $\begin{array}{c}0.34 \pm \\
.17\end{array}$ & - & $\begin{array}{c}0.34 \pm \\
0.12\end{array}$ & $\begin{array}{c}0.31 \pm \\
0.15\end{array}$ & - & $\begin{array}{c}0.49 \pm \\
0.06\end{array}$ & $\begin{array}{c}2.65 \pm \\
0.17\end{array}$ \\
\hline 100Gy & $\begin{array}{c}10.54 \pm \\
0.04^{c}\end{array}$ & $\begin{array}{c}0.37 \pm \\
0.19\end{array}$ & $\begin{array}{c}0.70 \pm \\
0.13\end{array}$ & 0 & $\begin{array}{c}0.72 \pm \\
0.17\end{array}$ & $\begin{array}{c}0.71 \pm \\
0.17\end{array}$ & - & - & - & $\begin{array}{c}0.37 \pm \\
0.19\end{array}$ & $\begin{array}{c}0.54 \pm \\
0.04\end{array}$ & $\begin{array}{c}3.59 \pm \\
0.13\end{array}$ \\
\hline 150Gy & $\begin{array}{c}9.41 \pm \\
.02^{\mathrm{d}}\end{array}$ & $\begin{array}{c}0.91 \pm \\
0.16\end{array}$ & $\begin{array}{c}1.32 \pm \\
0.28\end{array}$ & $\begin{array}{c}0.51 \pm \\
0.27\end{array}$ & - & $\begin{array}{c}0.90 \pm \\
0.16\end{array}$ & $\begin{array}{c}0.90 \pm \\
0.11\end{array}$ & - & - & - & - & $\begin{array}{c}4.54 \pm \\
0.09\end{array}$ \\
\hline 200Gy & $\begin{array}{c}8.34 \pm \\
0.23^{e}\end{array}$ & $\begin{array}{c}0.6 \pm \\
0.34\end{array}$ & $\begin{array}{c}1.10 \pm \\
0.56\end{array}$ & 0 & $\begin{array}{c}1.07 \pm \\
0.24\end{array}$ & $\begin{array}{c}1.07 \pm \\
0.24\end{array}$ & - & - & $\begin{array}{c}1.07 \pm \\
0.24\end{array}$ & $\begin{array}{c}0.40 \pm \\
0.20\end{array}$ & - & $\begin{array}{c}5.17 \pm \\
0.09\end{array}$ \\
\hline 250Gy & $\begin{array}{c}7.46 \pm \\
0.19^{f}\end{array}$ & $\begin{array}{c}0.59 \pm \\
0.29\end{array}$ & $\begin{array}{c}0.61 \pm \\
0.30\end{array}$ & $\begin{array}{c}1.04 \pm \\
.16\end{array}$ & $\begin{array}{c}0.59 \pm \\
0.29\end{array}$ & 0 & $\begin{array}{c}1.19 \pm \\
0.16\end{array}$ & $\begin{array}{c}0.74 \pm \\
0.38\end{array}$ & $\begin{array}{c}0.76 \pm \\
0.40\end{array}$ & - & $\begin{array}{c}0.89 \pm \\
0.44\end{array}$ & $\begin{array}{c}6.41 \pm \\
0.05\end{array}$ \\
\hline
\end{tabular}

Means followed by lowercase letters are statistically significant at $P \leq 0.05$.Abbreviations- Sc- Scattering; St- Stickiness; Un- Unorientation;

Pr-Precocious movement; Lg- Laggard; Br-Bridge formation 


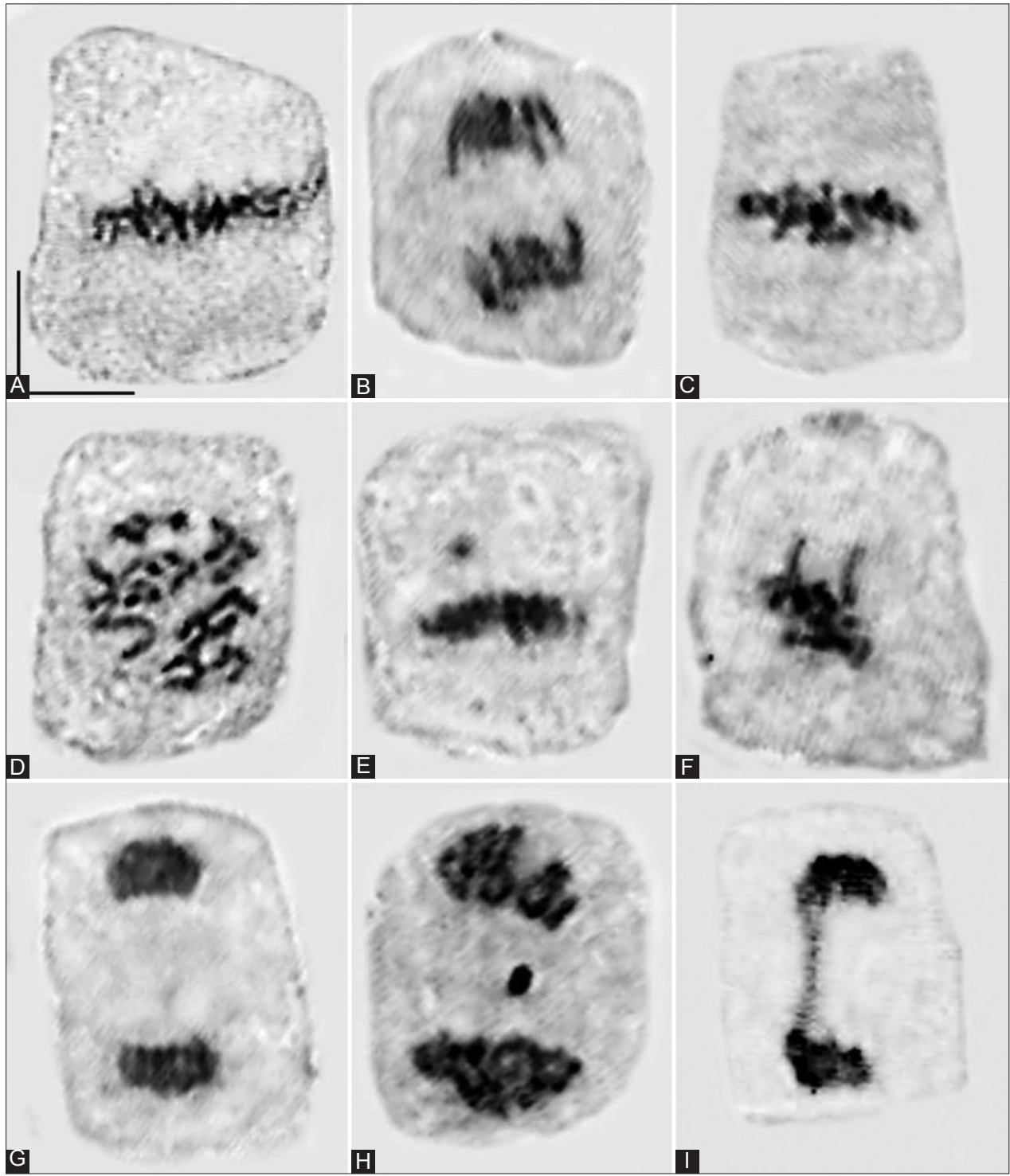

Figure 6: Different types of chromosomal aberrations induced by Gamma irradiation on Foeniculum vulgare Mill.: A-Normal Metaphase(2n=22), B-Normal Anaphase(22:22 separation), C-Stickiness at metaphase, D-scattaring at metaphase, E-Precocious at metaphase, F-loop formation at metaphase, G stickness as anaphase, $\mathrm{H}$ - Laggard at anaphase, I- Bridge formation at anaphase . Scale bar- Length $-6.30 \mathrm{~mm}$ Width $-5.40 \mathrm{~mm}$

a result increased chromosomal contraction and condensation or nucleoproteins that leading to cell death (Kumar \& Bhardwaj, 2018) (Fig 6 D,G).

Laggard chromosome might be depending upon the moving speed and process of an individual chromosome differing from normal ones (Fig $6 \mathrm{H}$ ). Bridged chromosome are therefore significantly cause due to furrow regression or due to chromosomal inversion which leads to formation of dicentric and acentric chromosomes, these dicentric chromosomes are involved in bridge formation (Kumar \& Dwivedi, 2013) (Fig 6 I). Ionising radiation induced Different type of chromosomal aberrations during the different intervening phases of cell cycle. It induced chromosome type of aberrations in $\mathrm{Gl}$ phase, chromatid type of aberrations in S-phase and G2 phase (Natarajan, 2002). Various researchers suggested that both the ionizing radiations and free radicals can generate changes in DNA in a different manner. Out of single stand breaks (SSBs) and double strand breaks (DSBs). Single stand breaks (SSBs) are the most abundant DNA lesions that arise from an oxidative attack, while double strand breaks (DSBs) are also commonly induced by ionizing radiations but most DSBs repair can be error prone, which is potentially detrimental for the cell. Both of these SSBs and DSBs can be repaired by cell cycle arrest mechanism. Damaged genetic constituents as aberrant chromosome repaired by check point in the cell cycle arrest in the meristematic cells which is most efficient mechanism to gain genomic stability. Previously some reports on the instability of genome is reported that G2 cell-cycle check point is very sensitive to ionizing radiation (Hefner et al., 2003; Preuss \& Britt 2003) And also confirmed that mito inhibitory effect of gamma irradiation on different plants and we are in the support of their findings. 


\section{CONCLUSION}

From the above study, we can conclude that gamma radiation is potential source for introducing chromosomal variations. Higher doses were found to be significantly chromotoxic. The cytological irregularities obtained in the results clearly depict the cytotoxic behavior of ionizing radiation. These types of studies are helpful to assess the hazardous effects of irradiation and to observe its consequences on biological systems. This research work could be further analyzed at meiotic level to generate elite genotype of the Fennel plant, Such a study could be useful in identifying the threshold dose of a mutagen although physical mutagen as gamma irradiation is a powerful mutagen, a beneficial doses of mutagen exposer that would enhance genetic variability as well as no of economically useful mutants in the fructifying generations .so it will be most conveniently helpful for developing more beneficial ,high yielding mutant and variant.

\section{ACKNOWLEDGMENTS}

Authors are highly obliged to NRCSS, Ajmer for providing seeds of Fennel plant. The lab members of Plant Genetics Laboratory should also be given the due credit for their support and valuable help.

\section{REFERENCES}

Ahloowalia, B. S., \& Maluszynski, M. (2001). Induced mutations-A new paradigm in plant breeding. Euphytica, 118, 167-173. https://doi. org/10.1023/A:1004162323428

Ahmad, S., \& Qureshi, S. (1992). Comparative study of two cultivars of Zea mays after seed irradiation. Sarhad Journal of Agriculture (Pakistan), 8, 167-173.

Ashraf, M. (2009). Biotechnological approach of improving plant salt tolerance using antioxidants as markers. Biotechnology Advances, 27, 84-93. https://doi.org/10.1016/j.biotechadv.2008.09.003

Bharathi, T., Gnanamurthy, S., Dhanavel , D., Murugan, S., \& Ariraman, M. (2013) Induced Physical mutagenesis on seed germination, lethal dosage and morphological mutants of Ashwagandha (Withania somnifera L.). International Journal of Advanced Research, 1, 136-141.

Casarett, A.P. (1968). Radiation biology, (No. TID-24693).

Chahal, G. S., \& Gosal, S. S. (2002). Principles and procedures of plant breeding Biotechnological and conventional approaches. Alpha Science Int'I Ltd, 399-412.

Din, R., Khan, M. M., Qasim, M., Jehan, S., \& Khan, M. M. I. (2003). Induced mutability studies in three wheat (Triticum aestivum L.) varieties for some morphological and agronomic characteristics. Asian Journal of Plant Sciences, 2, 1179-1182.

Gadano, A., Gurni A., Lo'pez, P., Ferraro, G., \& Carballo, M. (2002). In vitro genotoxic evaluation of the medicinal plant Chenopodium ambrosioides L. Journal of Ethnopharmacology, 81, 11-16. https:// doi.org/10.1016/S0378-8741(01)00418-4

Harten, A. M. (1998). Mutation breeding: theory and practical applications. Cambridge University Press.

Hefner, E., Preuss, S. B., \& Britt, A. B. (2003). Arabidopsis mutants sensitive to gamma radiation include the homologue of the human repair gene ERCC1. Journal of Experimental Biology, 54, 669-680. https://doi. org/10.1093/jxb/erg069

Khan, M., \& Musharaf, S. (2014). Foeniculum vulgare Mill. A medicinal herb. Medicinal Plant Research, 4, 46-54.

Kharkwal, M. C., \& Shu, Q. Y. (2009). The role of induced mutations in world food security. Induced plant mutations in the genomics era. Food and Agriculture Organization of the United Nations, Rome, 33-38.

Kovacs, E., \& Keresztes, A. (2002). Effect of gamma and UV-B/C radiation on plant cells. Micron, 33,199-210. 10.1016/s0968-4328(01)00012-9

Kumar, G., \& Bhardwaj, M. (2018). Induced genetic variations in Cuminum cyminum through supplemental UV-B radiation. Journal of Environmental Biology, 40, 342-348. https://doi.org/10.22438/ jeb/40/3/MRN-938

Kumar, G., \& Dwivedi, H. (2013). Genotoxic effects of heavy metals in Trachyspermum ammi (L.) Sprague. Chromosome Botany, 8, 81-86. https://doi.org/10.3199/iscb.8.81

Kumar, G., \& Rai, P. K. (2007). EMS induced karyomorphological variations in maize (Zea mays L.) inbreds. Turkish Journal of Biology, 31, 187-195.

Ling, A. P. K., Kiong, P., Lai, A. G., Hussein, S., Harun, A. R. (2008). Physiological responses of Orthosiphon stamineus plantlets to gamma irradiation. American-Eurasian Journal of Sustainable Agriculture, 2, 135-149.

Majeed, A., \& Muhammad, Z. (2010). Gamma irradiation effects on some growth parameters of Lepidium sativum $\mathrm{L}$. World Journal of Fungal and Plant Biology, 1, 8-11.

Melki, M., \& Sallami, D. (2008). Studies the effects of low dose of gamma rays on the behaviour of chickpea under various conditions. Pakistan Journal of Biological Sciences, 11, 2326-2330.

Moura, L. S., Carvalho, J. R., Stefanini, M. B., Ming, L. C., \& Meireles, M. A. A. (2005). Supercritical fluid extraction from fennel (Foeniculum vulgare): global yield, composition and kinetic data. The Journal of Supercritical Fluids, 35, 212-219. https://doi.org/10.1016/j. supflu.2005.01.006

Mudibu, J., Nkongolo, K. K. C., Mehes-Smith, M., \& Kalonji-Mbuyi, A. (2011) Genetic analysis of a soybean genetic pool using ISSR marker: effect of gamma radiation on genetic variability. International Journal of Plant Breeding and Genetics, 5, 235-245.

Natarajan, A. T. (2002). Chromosome aberrations: past, present and future. Mutation Research/Fundamental and Molecular Mechanisms of Mutagenesis, 504, 3-16. https://doi.org/10.1016/S00275107(02)00075-1

Preuss, S. B., \& Britt, A. B. (2003). A DNA-damage-induced cell cycle checkpoint in Arabidopsis. Genetics, 164(1), 323-334.

Somosy, Z. (2000). Radiation response of cell organelles. Micron, 31, 165181. https://doi.org/10.1016/S0968-4328(99)00083-9

Sudhakar, R., Gowda, K. N. N., \& Venu, G. (2001). Mitotic abnormalities induced by silk dyeing industry effluents in the cells of Allium cepa. Cytologia, 66, 235-239. https://doi.org/10.1508/cytologia.66.235

Verma, A. K., Sharma, S., Kakani, R. K., Meena, R. D., \& Choudhary, S. (2017). Gamma radiation effects seed germination, plant growth and yield attributing characters of fennel (Foeniculum vulgare Mill.). International Journal of Current Microbiology and Applied Sciences, $6(5), 2448-2458$ 